ZOOLOGIA 27 (4): 646-648, August, 2010

doi: $10.1590 /$ S1984-46702010000400012

\title{
Eutaleola, a replacement name for the homonym Euteleia (Bryozoa: Pasytheidae)
}

\author{
Leandro M. Vieira' \& Dennis P. Gordon²
}

\author{
${ }^{1}$ Departamento de Zoologia, Instituto de Biociências, Centro de Biologia Marinha, Universidade de São Paulo. \\ 11600-000 São Sebastião, SP, Brazil.Email: leandromanzoni@hotmail.com \\ ${ }^{2}$ National Institute of Water \& Atmospheric Research (NIWA). Private Bag 14-901, Kilbirnie, Wellington, New Zealand. \\ Email: d.gordon@niwa.co.nz
}

\begin{abstract}
Eutaleola nom. nov. is proposed as a replacement name for Euteleia Marcus, 1938 (Bryozoa: Cheilostomata), a secondary homonym of Euteleia Raffray, 1904 (Arthropoda: Coleoptera). Eutaleola is a monospecific genus of Pasytheidae, found in warm shallow waters on both sides of the Atlantic and in deeper waters of the eastern Pacific. Brazilian material of Eutaleola evelinae (Marcus, 1938) comb. nov. is described and illustrated.
\end{abstract}

KEY WORDS. Cheilostomata; homonymy; new name.

MARCus (1938) introduced a new monotypic genus for a new species Euteleia evelinae, an inconspicuous encrusting pasytheid bryozoan from Santos, Brazil. The original spelling, Euteleia, continued to be used by Marcus (1949) and was cited thus by BASSLER (1953) in the Bryozoa volume in the "Treatise on Invertebrate Paleontology" series. Later, the original spelling was also used by LaGAAIJ (1973) in his account of Late Pleistocene bryozoan fragments encountered in sandy sediments of the Nigeria-Cameroon shelf. Соок $(1968,1985)$ inadvertently misspelled the name "Eutaleia", which she attributed to Marcus (1938), so it is clear this was a lapsus calami, not a deliberate attempt to correct the spelling, as there was no discussion of the spelling and no mention of homonymy. Following Соок $(1968,1985)$, Vieira et al. (2008) used the variant spelling Eutaleia in their checklist of Recent bryozoans of Brazil, but this usage does not make Eutaleia an available name (ICZN 1999: Art. 33.3, Incorrect subsequent spellings), as well as this spelling does not constitute "prevailing usage", for the species has been infrequently encountered and little reported on. The current Bryozoa Home Page entry for Euteleia [http:/ /bryozoa.net/cheilostomata/pasytheidae/euteleia.html] uses Marcus's (1938) original spelling and notes that Eutaleia is a misspelling.

The name Euteleia was first proposed by RAFFRAY (1904) for a species of Coleoptera - Euteleia nodosa Raffray, 1904. Under the International Code of Zoological Nomenclature (ICZN 1999: art. 52.2), Euteleia Marcus, 1938 must be rejected. We propose here the replacement name Eutaleola nom. nov. and re-illustrate the type species. The figured specimens are deposited in the Bryozoa Collection of Museu de Zoologia da Universidade de São Paulo (MZUSP).

\section{TAXONOMY}

\section{Eutaleola nom. nov.}

Euteleia Marcus, 1938: 33. Secondary homonym of Euteleia Raffray, 1904.

Eutaleia (lapsus calami): Cook, 1968: 178; 1985: 140; FlórezRomero et al., 2007: 241; Montoya-Cadavid et al., 2007: 169; Vieira et al., 2008: 23.

Type species. Euteleia evelinae Marcus, 1938, by monotypy and original designation.

Etymology. L. taleola $($ diminutive of talea $)=$ slender staff.

\section{Eutaleola evelinae (Marcus, 1938) comb. nov.}

Figs $1-3$

Euteleia evelinae Marcus, 1938: 33, pl. 8, figs 18B-D, pl. 9, fig. 18; Osburn, 1952: 289, pl. 31, fig. 4; Lagaaij, 1973: 143, 146, pl. 2, figs 14,15 .

Eutaleia (sic) evelinae: Cook, 1968: 178, pl. 9C; 1985: 140, fig. 26g; Flórez-Romero et al., 2007: 241, fig. 3.

Description. Colonies encrusting, unilaminar, with mostly uni-pluriserial, occasionally even multiserial, branching rows of well-calcified zooids, yellowish to transparent-white in color. Autozooids pyriform/subclavate, distally truncate and inflated, $0.30-0.50 \mathrm{~mm}(0.398 \pm 0.054)$ length and $0.15-0.25$ $\mathrm{mm}(0.204 \pm 0.028)$ width; narrower proximal portion, connected by chitinous joint to parent zooid. Frontal wall (frontal shield) gymnocystal, with small regularly spaced pores. Primary orifice $0.10-0.12 \mathrm{~mm}(0.108 \pm 0.010)$ length and $0.08-0.10 \mathrm{~mm}$ $(0.094 \pm 0.009)$ width, subterminal in zooid, inclined distalward; 

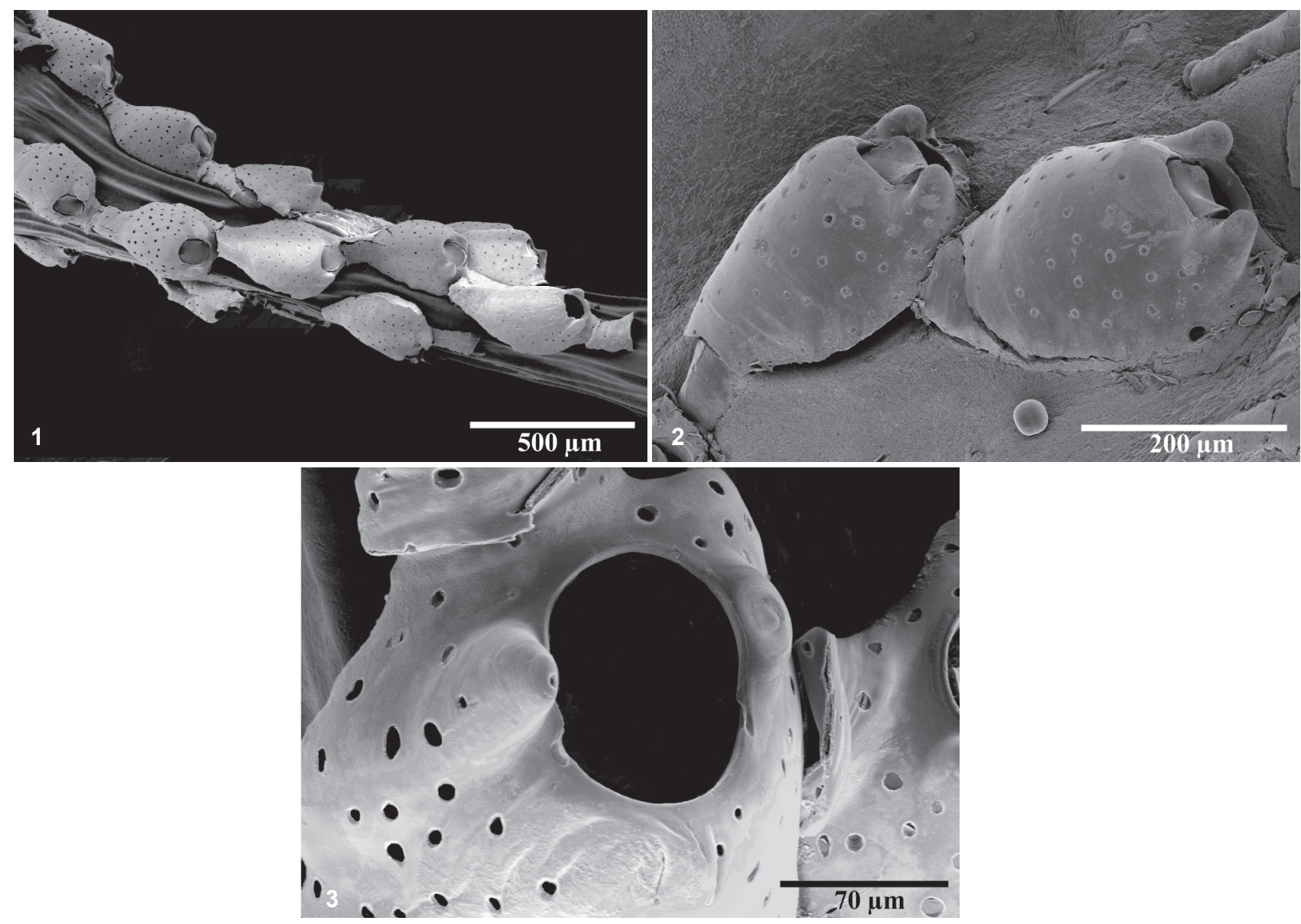

Figures 1-3. Scanning electron microscopy of E. evelinae comb. nov.: (1) Ceará, Brazil (MZUSP 0190), colony on hydroid; (2) Alagoas, Brazil (MZUSP 0250), lateral view of two zooids on algae; (3) Ceará, Brazil (MZUSP 0190), detail of oral region.

anter arched, separated from shallow and wider poster by small rounded condyles. Oral spines absent. On each side of orifice a rounded tubercle, slightly angled distally bent inward. Avicularia and ovicells absent.

Material examined. BraziL, Alagoas: Jequiá da Praia (Jacarecica do Sul), $20 \mathrm{~m}$, on Sertulariidae (Hydrozoa), 19.x.2002, L.M.Vieira \& M.D. Correia leg., MZUSP 0248. Alagoas: Maceió (Beach of Jacarecica, 9 $9^{\circ} 36^{\prime} 50^{\prime \prime} \mathrm{S}, 35^{\circ} 41^{\prime} 12^{\prime \prime} \mathrm{W}$ ), intertidal, colonies on algae, II.2004, L.M.Vieira leg., MZUSP 0249. Alagoas: Maceió (Beach of Sereia, $9^{\circ} 33^{\prime} 55^{\prime \prime}$ S, 35³8'40"W), intertidal, colonies on algae, 07.IX.2007, A.G.A.Borba Jr leg., MZUSP 250. Ceará: Fortaleza (Beach of Náutico), intertidal, colonies on Thyroscyphus sp. (Hydrozoa), 25.VIII.2009, L.M.Vieira leg., MZUSP 0190.

Remarks. Owing to the sum of the zooidal characters, this species was transferred to the Pasytheidae Davis, 1934 by Соок (1985) from the Savignyellidae Levinsen, 1909 in which it was placed by MArcus (1938). Eutaleola evelinae (Marcus, 1938) is characterized by its repent habit, its gymnocystal frontal shield with numerous small perforations, and the complete lack of articulated oral spines, avicularia and ovicells. The colonies may form small and inconspicuous uniserial colonies, loosely encrusting on algae and hydroids, becoming pluriserial through repeated budding of zooid rows in close proximity. Osburn (1952) suggested that E. evelinae can be very common in shallow shelf depths but it tends to be easily overlooked owing to its inconspicuous colonies and its habit of closely adhering to stems of hydroids and algae.

VIeIRA et al. (2010) discussed the occurrence of certain wide-ranging bryozoans in shallow waters of the Western Atlantic, from the Caribbean to northeastern Brazil, despite the existence of some oceanographic and biogeographic barriers not conducive to their dispersal. Eutaleola evelinae is one such bryozoan, supporting a suggested biogeographic affinity between the bryozoan fauna of the Caribbean and Brazil (see VIEIRA et al. 2010). However, this species is not restricted to the Western Atlantic but has a circumtropical distribution on both sides of the Atlantic (Cook 1985) and in the Eastern Pacific (OsburN 
1952). This pattern of distribution is unusual among cheilostomatous bryozoans because their larvae are predominantly lecithotrophic and short-lived. According to NARANJo et al. (1998), some amphi-Atlantic distributions in marine species can be explained by dispersal on naturally drifting or anthropogenic substrata. TAYLOR \& MonKs (1997) showed that the occurrence of some widespread species of Bryozoa can be explained by transport on drifting objects (e.g. algae, planktonic shells and plastic). Therefore, the equatorial current can make possible a connection between eastern and western Atlantic bryozoans that attach to pelagic algae, viz. Eutaleola evelinae, Beania klugei Cook, 1968, Jellyella tuberculata (Bosc, 1802) and Catenicella contei (Audouin, 1826), which are recorded on both side of Atlantic (CoOK 1985, Vieira et al. 2008).

Although, on the one hand, a circumtropical distribution is unusual in invertebrates with a short-lived larva (CoelHo et al. 2008), some species have been discovered to have a distribution on both sides of the Isthmus of Panama. Although several fossil fragments of E. evelinae had been collected in Nigerian shelf sediments (later Pleistocene) (LagaAIJ 1973), the occurrence of this species in the eastern Pacific and the Caribbean can be related to the closure of the Isthmus. Comparison of bryozoan faunas in the most comprehensive publications from the tropical eastern Atlantic (CoOK 1985) and western Atlantic (WINSTON 2005, VIEIRA et al. 2008) identifies a small number of species (ca. 10) with an amphi-Atlantic distribution.

Overall, Eutaleola evelinae has been reported in shallow water from the western Atlantic (Brazil and Colombia) and southeastern Atlantic (Ghana and Nigeria), as well as in deeper water (to $140 \mathrm{~m}$ depth) from the eastern Pacific (Peru, Panamá and California). This unusual distribution warrants further investigation concerning morphological and genetic variability.

\section{ACKNOWLEDGMENTS}

We are grateful to Judith E. Winston (Virginia Museum of Natural History, USA) for suggestions concerning this paper and to Phil Bock (Melbourne) and Mary Spencer Jones (Natural History Museum, UK) for discussion. We also thank Lara Maria Guimarães (Museu de Zoologia, Universidade de São Paulo) for help with scanning electron microscopy. Funding was provided by FAPESP (Proc. 06/05141-8) to Leandro M. Vieira. Dennis Gordon's research was supported by the New Zealand Foundation for Research, Science \& Technology (Contract C01X0502).

\section{LITERATURE CITED}

BASSLER, R.S. 1953. Treatise on Invertebrate Paleontology, Part G: Bryozoa. Kansas, Geological Society of America and University of Kansas Press, XII+253p.

Coelho, P.A.; A.O. Almeida \& L.E.A. Bezerra. 2008. Checklist of the marine and estuarine Brachyura (Crustacea: Decapoda) of northern and northeastern Brazil. Zootaxa 1956: 1-58.
Cook, P.L. 1968. Bryozoa (Polyzoa) from the coasts of tropical West Africa. Atlantide Report 10: 115-262.

Cook, P.L. 1985. Bryozoa from Ghana - a preliminary survey. Annales de la Musée royale de l'Afrique centrale (Sciences zoologiques) 238: 1-315.

Flórez-Romero, P.; E. Montoya-Cadavid; J. Reyes-Forero \& N. Santodomingo. 2007. Briozoos cheilostomados del Caribe colombiano. Boletin de Investigaciones Marines y Coteras 36: $229-250$

ICZN. 1999. International Code of Zoological Nomeclature. London, International Trust for Zoological Nomeclature, $4^{\text {th }}$ ed., $\mathrm{XX}+365 \mathrm{p}$.

LagaAI, R. 1973. Shallow-water Bryozoa from deep-sea sands of the Principe Channel, Gulf of Guinea, p. 139-151. In: G.P. Larwood (Ed.). Living and Fossil Bryozoa - Recent Advances in Research, Proceeding of the International Bryozoology Association conference. New York, Academic Press, XVII+634p.

Marcus, E. 1938. Bryozoários marinhos brasileiros, 2. Boletim da Faculdade de Filosofia, Ciências e Letras da Universidade de São Paulo, Zoologia 2: 1-196.

Marcus, E. 1949. Some Bryozoa from the Brazilian coast. Comunicaciones Zoológicas del Museo de Historia Natural de Montevideo 3 (53): 1-33.

Montoya-Cadavid, E.; P. Flórez-Romero \& J.E. Winston. 2007. Checklist of the marine Bryozoa of the Colombian Caribbean. Biota Colombiana 8 (2): 159-184.

Naranjo, S.; J.L. Carvaloo \& J.C. García-Gómez. 1998. Towards a knowledge of marine boundaries using ascidians as indicators: characterising transition zones for species distribution along Atlantic-Mediterranean shores. Biological Journal of the Linnean Society 64: 151-177.

Osburn, R.C. 1952. Bryozoa of the Pacific coast of America, part 2, Cheilostomata-Ascophora. Report of the Allan Hancock Pacific Expeditions 14: 271-611.

Raffray, A. 1904. Genera et catalogue des Psélaphides. Annales de la Société Entomologique de France 73: 1-400.

TAYLOR, P.D. \& N. Monks. 1997. A new cheilostome bryozoans genus pseudoplanktonic on molluscs and algae. Invertebrate Biology 116: 39-51.

Vieira, L.M.; A.E. Migotto \& J.E. Winston. 2008. Synopsis and annotated checklist of Recent marine Bryozoa from Brazil. Zootaxa 1810: 1-39.

Vieira, L.M.; A.E. Migotto \& J.E. Winston. 2010. Marcusadorea, a new genus of lepralioid bryozoan from warm waters. Zootaxa 2348: 57-68.

Winston, J.E. 2005. Re-description and revision of Smitt's "Floridan Bryozoa" in the collection of the Museum of Comparative Zoology, Harvard University. Virginia Museum of Natural History Memoir Number 7: 1-147.

Submitted: 19.VII.2009; Accepted: 11.VII.2010.

Editorial responsibility: Marcos D.S. Tavares 